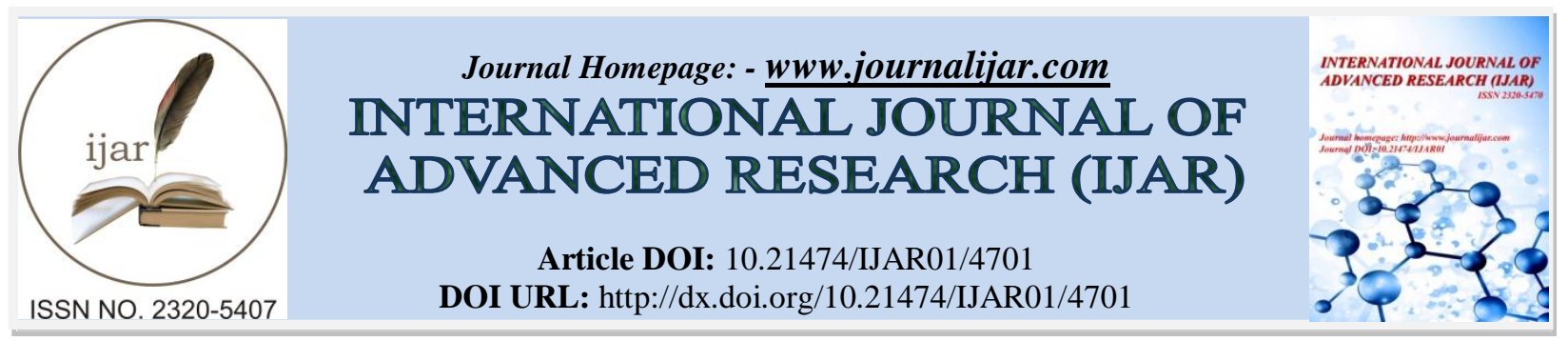

RESEARCH ARTICLE

\title{
A STUDY TO ASSESS PATIENT'S SATISFACTION WITH QUALITY OF NURSING CARE IN NEUROMEDICAL DEPARTMENT IN SELECTED HOSPITAL OF HARYANA.
}

\author{
Sheuli Sen. \\ Professor, Department of Pediatrics Nursing, Amity College of Nursing, Amity University, Gurgaon, Haryana, \\ India.
}

\section{Manuscript Info}

........................

Manuscript History

Received: 2 May 2017

Final Accepted: 4 June 2017

Published: July 2017

\section{Abstract}

Objectives: - (i) To assess the patient satisfaction with quality of nursing Care. (ii) To identify relationship between satisfaction of patient with selected variables.

Method: - In this study descriptive survey approach was used. Purposive sampling technique was used and study sample was 50 adult patients who admitted in the Neuro MICU (Medical Intensive Care Unit) and Neuro Medical ward of SGT Hospital. The total period of sample collection was from January 2016 to April 2016.The data collection tool used for the study was a modified form of Dr. Laschinger's -"Patient satisfaction with quality nursing care questionnaire" [PSNCQQ], translated to vernacular language Hindi.

Result:-The total number of sample was 50. The mean age of sample was 44.7 yrs. Majority of the samples $70 \%$ were reported good, $30 \%$ were reported excellent and no one reported poor. In this study there is no significant relation between patient satisfactions with quality of nursing care by different variables. There was statistically significant relation between age and satisfaction of patient (p-0.031) and no relation between other variables.

Copy Right, IJAR, 2017,. All rights reserved.

\section{Background of the study:-}

Patient satisfaction has become increasingly popular, as a critical component in the measurement of quality of care. Satisfaction is one of the cares out come for healthcare. Satisfaction with health care is measure with a long history in the social science. Nursing service is one of the most important components of hospital service. Understanding how things are looking through the patient's eye should be central part of quality improvement. The level of patient satisfaction with nursing care is an important indicator of quality of care provided in hospitals [Laschinger et al., 2005].

Patient satisfaction is a term that can be interpreted differently by patients and it meaning can also differ for one patient at different times. Patient's satisfaction some time treated as an outcome measure of healthcare providers. A satisfied patient is more willing to recommend the hospital to provide his or her care to others. [Abramowitz et al., 1987]

Patient places high value on the interpersonal care provided by the nursing staff. Consumers of health care industry demand quality care and one measure of quality is patient's satisfaction. Patient's satisfaction is an indicator of quality of care from patient's perspective. 
Patient's satisfaction is defined as patient's subjective evaluation of their cognitive and emotional reaction as a result of interaction between their expectation regarding ideal nursing care and their perceptions of actual nursing care [Erikson1987].

Definition of nursing care is to promote health and to help support, educate and develop patient by liberating his or her own resources. The nursing care provided by nurse is regarded as most important factor in patient assessment of their satisfaction with health care. If patient is satisfied with health care received, this is positive not only for individual but also for nurse and entire health care organization (Johansson et al; 2002

According to the American Nurses Association, "Nursing practice is a direct service, goal directed and adaptable to the needs of the individual, the family and community during health and illness. The nurse's primary responsibility is to those people who require nursing care.

Instruments measuring patient's satisfaction have often been focused on in patient treatment [Muntlin et al., 2006]. Nursing care has a prominent role in patient satisfaction, patient satisfaction is an important indicator of quality of care and healthcare facilities are interested in maintaining high levels of satisfaction in order to stay competitive in healthcare market [Wagner et al., 2009].The main indication for measuring patient satisfaction with nursing care is to identify area for improvement.

During hospitalization patient's satisfaction represents a balance between patient's perception and exceptions of their nursing care. Patient's satisfaction is important patient-centered out come to measure, is accepted as standard measure of quality of care and it is steadily gaining in popularity.

Today's nurse engages in approximately eight inter related roles: -care giver, advocate, critical thinker, teacher, communicator, manager, researcher \& rehabilitator [Harkreader and Hogan2004]. Patient satisfaction with nursing care has consistently been found to be correlated with overall satisfaction care and has been defined as the patient subjective evaluation of the cognitive and emotional response that result from interaction the patients' expectation of nursing care and their perception of actual nurse behavior and characteristics [Erickson.,1987].

Nursing is a process of recognizing; understanding and meeting health needs of any person or society and is based on constantly changing the body of scientific knowledge. Nurses and physicians perceptions about good quality of care do not always agree with patient's perceptions. Nursing is an accountable profession guided by science, theory, code of ethics and the art of care and comfort to treat human responses to health and ill Patient's satisfaction with nursing care is considered as an important factor in explaining patient's perception of service quality.

The nurse work environment has being found to be both directly and indirectly related to patient's satisfaction [Vahey. 2004]. Patient's satisfaction has been advocated as an outcome measure of quality nursing care. Determinants quality of nursing care include: adequate skill, caring attitudes, effective communication, efficient organizational and management systems, and effective participation.

\section{Need of the study:-}

Nursing care is recognized as an area subjected to competition, where the patient is seen both as a client and consumer of health care. To improve quality of nursing care, nurses need to know what factors influence patient satisfaction. Nursing care plays the key role in providing satisfaction in this arena.

Quality of nursing care is vital to patient outcomes and safety. Patient satisfaction with nursing care is strongly associated with patients overall satisfaction with hospital experience. To ensure service improvement initiatives at appropriative levels in hospital is a prerequisite to understand factors which influence patient satisfaction with nursing care. The measurement of patient satisfaction with nursing care is important to determine and meet patient's need in terms of care and to evaluate quality of care provided.

Patients in the Neuromedical unit needs prolonged hospital stay. Prolonged hospital stay itself can cause health care associated infections, psychological stress and complication like bed sore, hydrostatic pneumonia etc. So nurse should focus giving in holistic care to the patient in order to prevent or limit the complication and for easy recovery. So assessing patient satisfaction can bring new changes in approach or modification in nursing care. 


\section{Objectives of the study:-}

To assess the patient satisfaction with quality of nursing care.

To identify relationship between satisfaction of patient with selected variables.

Variables of the study:-

Research variables: Patient satisfaction with nursing care quality.

Selected variables: Age, gender, marital status, number of times hospitalized in the past 2 years including the most recent hospital stay, overall how would you rate your health before this most recent hospital stay, were you got admitted, for most of your hospital stay, were you in a room.

\section{Conceptual Framework:-}

Conceptual framework based on modified J.W. Kenny General System model

(Source J.W. Kenny system model, WHO SEAROS technical publication 1985)

\section{Methodology:-}

Study approach: In this study, the researcher intends to assess the patient's satisfaction with quality of nursing care in Neuromedical department in selected hospital of Haryana, therefore a Survey approach was adopted for the study.

\section{Study Design:}

Descriptive Survey Design was found to be most appropriate design for the study.

Study settings: Neuromedical ICU and Neuromedical Ward in Neuromedical

ICU and Neuromedical Ward in Shree Guru Gobind Singh Tercentenary Hospital Gurgaon, Haryana.

\section{Population:-}

Target population: Male and female patients who are diagnosed with neuromedical condition and the line of treatment as well as nursing management referred in this aspect.

Accessible population: Both male and female patients admitted in neuromedical unit in SGT Hospital, Gurgaon and present during the day of data collection.

\section{Sample:}

Both male and female patients admitted in Neuromedical intensive care unit (NMICU) neuromedical unit (NM) in SGT Hospital, Gurgaon

\section{Sample size:-}

The sample size consists of 50 patients who fulfill the inclusion criteria selected for the study. The inclusion criteria for sample selection were

\section{Inclusion criteria:-}

Patients who are willing to participate

Patients who can read and understand Hindi

Patients who are for discharge on the day of data collection.

Patients who have age above 18 years.

\section{Exclusion criteria:-}

Patients on ventilator

Patients who do not respond/ disoriented/altered mental status

\section{Sampling technique:-}

Patients who are in neuromedical unit during data collection period and who fulfilled inclusion criteria were collected as samples by using Non-Probability Purposive Sampling Technique.

Tool: A modified form of Dr. Laschinger's- "Patient satisfaction with quality nursing care questionnaire" [PSNCQQ], translated to vernacular language Hindi. 


\section{Delimitation:-}

The study is delimited to patients in neuromedical ward and neuromedical ICU in Shree Guru Gobind Singh Tercentenary Hospital of Haryana and patients above 18 years of age.

Data collection tool \& method of data collection

Table 1:- Data collection tools and technique

\begin{tabular}{|l|l|l|l|}
\hline S.No & Variable To Be Measured & Tool & Techniques \\
\hline 1. & $\begin{array}{l}\text { General information or demographic data, it } \\
\text { includes Name, age, sex marital status, } \\
\text { education, category, date of admission, number of } \\
\text { previous admission, way of admission and } \\
\text { diagnosis }\end{array}$ & $\begin{array}{l}\text { Aaschinger's- form of Dr. } \\
\text { satisfaction with quality nursing } \\
\text { care questionnaire" [PSNCQQ], } \\
\text { translated to vernacular } \\
\text { language Hindi. }\end{array}$ & $\begin{array}{l}\text { Technique } \\
\text { 2. }\end{array}$ \\
\hline
\end{tabular}

Data collection tool refers to instrument which was used by investigator to obtain relevant data. A modified questionnaire was prepared by investigator from Dr. Laschingers. The questionnaire was translated to regional language Hindi with some modifications. The tool was examined by experts of SGT Hospital. The research tool was finalized according to expert's opinion.

\section{Development And Description Of The Tool:-}

As per the study purpose and objectives two tools were developed following the stepsextensive review of research and non research literature consultation with experts in the field and related fields developing blue print of the tool establishing content validity by formally seeking the suggestions and recommendations of seven experts in the field of child health nursing item analysis establishing reliability of the tool administering the tool for a try-out pilot study

\section{Tool I:-}

A modified form of Dr. Laschinger's- "Patient satisfaction with quality nursing care questionnaire" [PSNCQQ]. Laschinger et al [2005] prepared PSNCQQ; the questionnaire was five point rating scale consisting of nursing care during hospital stay.

The rating scales were - excellent, very good, good, fair, and poor.

The questionnaire was translated to regional language Hindi with some modification.

The structured questionnaire consists of two sections.

General information or demographic data, it includes Age, sex, marital status, education, income category, length of stay, number of previous admission.

20 questions regarding patient satisfaction with nursing care. The options given for rating were: excellent, very good, good, fair and poor.

\section{Reliability:-}

Reliability of structured questionnaire on "Patient satisfaction with quality nursing care" was established by using Split-half method \& Spearman brown prophecy formula. The reliability for the structured questionnaire was 0.85 , which was considered to be reliable.

\section{Ethical Implication:-}

$>$ The ethical permission for the data collection procedure were taken from the following

$>$ Administrative permission from the Chief operating officer (COO) of the SGT Hospital.

$>$ Ethical permission from the ethical committee.

$>$ Permission from the Medical Superintendent \& Nursing Superintendent.

$>$ Informed oral consent from the participant of the study.

$>$ Confidentiality of the participant has been maintained

$>$ Study Findings: The data's in this study analyzed and arranged under following sections

$>$ Distribution of samples according to demographic variables.

$>$ Distribution of samples according to information given by nurses.

$>$ Distribution of samples according to quality of nursing care. 
Distribution of sample based on association of overall satisfaction with nursing care and selected variables.

Distribution of samples according to demographic variable

Table 1:- Distribution of sample by age $\mathrm{N}=50$

\begin{tabular}{|c|c|c|}
\hline Age Group & Frequency & Percentage (\%) \\
\hline$<20$ & 3 & 20 \\
\hline $21-30$ & 10 & 14 \\
\hline $31-40$ & 7 & 24 \\
\hline $41-50$ & 12 & 12 \\
\hline $51-60$ & 6 & 16 \\
\hline $61-70$ & 8 & 8 \\
\hline $71-80$ & 4 & 100 \\
\hline Total & 50 & 16,88, mo \\
\hline
\end{tabular}

The age of sample ranges from18-78 with a mean age of 44.7, standard deviation 16.88, majority of samples were from age group 41-50 and only $6 \%$ were from age group $<20$.

Table 2 :-shows distribution of sample according to income category $\mathrm{N}=50$

\begin{tabular}{|c|c|c|}
\hline Category & Frequency & Percentage \\
\hline A & 3 & 18 \\
\hline B1 & 9 & 16 \\
\hline B & 8 & 6 \\
\hline C & 3 & 54 \\
\hline D & 27 & 100 \\
\hline Total & 50 & \\
\hline
\end{tabular}

Table2. Shows that majority of samples (54\%) were D category, only (6\%) were A category and (6\%) were C category.

Table 3:- Distribution of sample according to length of hospital stay $\mathrm{N}=50$

\begin{tabular}{|c|c|c|}
\hline Length of stay in days & Frequency & Percentage \\
\hline$\leq 10$ days & 38 & 24 \\
\hline$>10$ days & 12 & 100 \\
\hline Total & 50 & 24 \\
\hline
\end{tabular}

Table 3 shows that majority of sample 41(82\%) stay <=10 day, only 9(18\%) were more than 10 days.

Table 4 : -Distribution of sample according to sex. $\mathrm{N}=50$

\begin{tabular}{|c|c|c|}
\hline Sex & Frequency & Percentage \\
\hline Male & 33 & 66 \\
\hline Female & 17 & 34 \\
\hline Total & 50 & 100 \\
\hline
\end{tabular}

Table 4 Shows distribution of sample according to sex. There majority of sample were male (66\%) and only (34\%) in female sample.

Table 5:- Distribution of sample by marital status $\mathrm{N}=50$

\begin{tabular}{|l|l|l|}
\hline Marital status & Frequency & Percentage \\
\hline Single & 9 & 18 \\
\hline Married & 41 & 82 \\
\hline Total & 50 & 100 \\
\hline
\end{tabular}

Table 5 shows that distribution of sample by marital status. Majority of sample were married (82\%). 41(82\%) were married and $9(18 \%)$ were single. 
Table 6 :- Distribution of sample according to education $\mathrm{N}=50$

\begin{tabular}{|c|c|c|}
\hline Education & Frequency & \multicolumn{2}{c|}{ Percentage } \\
\hline School & 25 & 24 \\
\hline Pus two & 12 & 20 \\
\hline Graduate & 10 & 6 \\
\hline Post graduate & 3 & 100 \\
\hline Total & 50 & \\
\hline
\end{tabular}

Table 6 shows that the majority of sample had school education (50\%), only $6 \%$ percentage had post graduate education.

Table 7:- Distribution of sample according to previous admission $\quad \mathrm{N}=50$

\begin{tabular}{|c|c|c|}
\hline Previous admission & Frequency & Percentage \\
\hline Yes & 36 & 72 \\
\hline No & 14 & 28 \\
\hline Total & 50 & 100 \\
\hline
\end{tabular}

Table 7 Distribution of sample according to previous admission.36 (72\%) patients were previously admitted and $14(28 \%)$ patients not previously admitted.

Table 8:- Distribution of sample according to diagnosis $\mathrm{N}=50$

\begin{tabular}{|c|c|c|}
\hline Diagnosis & Frequency & Percentage \\
\hline Myasthenia gravis & 9 & 18 \\
\hline Vasculitis & 2 & 4 \\
\hline Multiple sclerosis & 6 & 4 \\
\hline Tb meningitis & 2 & 62 \\
\hline Encephalitis & 31 & 100 \\
\hline Total & 50 & 12 \\
\hline
\end{tabular}

Table 9:- Shows patient's satisfaction about information given by nurses. $\mathrm{N}=50$

\begin{tabular}{|c|c|c|}
\hline $\begin{array}{c}\text { Patient's satisfaction Information given by nurses. } \\
\text { about }\end{array}$ & Frequency & 2 \\
\hline Poor & 1 & 76 \\
\hline Good & 38 & 22 \\
\hline Excellent & 11 & 100 \\
\hline Total & 50 & \\
\hline
\end{tabular}

Table 9 shows that patient's satisfaction about information given by nurses. Only $2 \%$ samples rated poor. $38(76 \%)$ samples rated good and $11(22 \%)$ rated excellent.

Table 10:- Distribution of sample based on patients' satisfaction about information given by nurses and age group. The age of sample ranges from $18-78$ with a mean age of 44.7, standard deviation 16.88 . $\mathrm{N}=50$

\begin{tabular}{|l|l|l|l|l|l|l|}
\hline \multirow{2}{*}{\begin{tabular}{l} 
Satisfaction of patient $\begin{array}{l}\text { Age }<45 \\
\text { by information given } \\
\text { by nurses }\end{array}$ \\
\cline { 2 - 8 }
\end{tabular}} & \multicolumn{2}{|l|}{ Frequency } & \multicolumn{2}{l|}{ Frequency $(\%)$} & \multicolumn{2}{l|}{ Frequency $(\%)$} \\
\cline { 2 - 8 } & $(\%)$ & & & & \\
\hline Poor & 1 & $(4 \%)$ & & 0 & 1 & $(2 \%)$ \\
\hline Good & 22 & $(88 \%)$ & 16 & $(64 \%)$ & 38 & $(76 \%)$ \\
\hline Total & 2 & $(8 \%)$ & 9 & $(36 \%)$ & 11 & $(22 \%)$ \\
\hline
\end{tabular}

Table 9 shows that patients with $\geq 45$ years $64 \%$ rated good. Among that $36 \%$ rated excellent and no one reported poor. Among <45 yrs $88 \%$ were rated good, $2(8 \%)$ were rated excellent and only $4 \%$ were rated poor.

Table 10:- Distribution of sample based patients' satisfaction about information given by nurses according to sex. $\mathrm{N}=50$

\begin{tabular}{|l|l|l|l|}
\hline Satisfaction of the & Female & Male & Total \\
\cline { 2 - 4 } Patient & Frequency (\%) & Frequency (\%) & Frequency $(\%)$ \\
\hline Poor & 0 & 1 & 1 \\
\hline
\end{tabular}




\begin{tabular}{|l|l|l|l|}
\hline & & $(3.03 \%)$ & $(2 \%)$ \\
\hline Good & $13(76.47 \%)$ & $25(75.76 \%)$ & $\begin{array}{l}38 \\
(76 \%)\end{array}$ \\
\hline Excellent & $4(23.53 \%)$ & $7(21.21 \%)$ & $\begin{array}{l}11 \\
(22 \%)\end{array}$ \\
\hline Total & $\begin{array}{l}53 \\
(17)\end{array}$ & $\begin{array}{l}33 \\
(100 \%)\end{array}$ \\
\hline
\end{tabular}

Table 10 shows that majority of sample $38(76 \%)$ rated good, $22 \%$ rated excellent and only $2 \%$ were rated poor. Among females 13(76.47\%) rated good, 23.53\% rated excellent and no one reported poor. Among males and $25(75.76 \%)$ rated good, $21.21 \%$ were rated excellent and $3.03 \%$ rated poor.

Table 11:- shows distribution of sample based on patientse satisfaction about information given by nurses and marital status. $\mathrm{N}=50$

\begin{tabular}{|c|c|c|c|}
\hline $\begin{array}{c}\text { Satisfaction of } \\
\text { Patient }\end{array}$ & Single & Married & Total \\
\cline { 2 - 4 } & Frequency $(\%)$ & Frequency $(\%)$ & Frequency $(\%)$ \\
\hline Poor & 0 & $1(2.44 \%)$ & 1 \\
& & & $3 \%)$ \\
\hline Good & $7(77.78 \%)$ & $31(75.61 \%)$ & 38 \\
& & & $11(22 \%)$ \\
\hline Excellent & $2(22.22 \%)$ & $9(21.95 \%)$ & $50(100 \%)$ \\
\hline Total & $9(100 \%)$ & $41(100 \%)$ & \\
\hline
\end{tabular}

Table 11 shows that $22.22 \%$ rated excellent, $76 \%$ were rated good and $2 \%$ rated poor. Among single $77.78 \%$ rated good, $22.22 \%$ were rated excellent. Among married $21.95 \%$ rated excellent, $75.61 \%$ were rated good and only $2.44 \%$ rated poor. There is no relationship between marital status and information given by nurses.

Table 12:- Distribution of sample based on patients' satisfaction about information given by nurses and educational status. $\mathrm{N}=50$

\begin{tabular}{|c|c|c|c|}
\hline \multirow{2}{*}{$\begin{array}{c}\text { Satisfaction } \\
\text { of patient }\end{array}$} & School \& plus2 & Graduate \& post & Total \\
\cline { 2 - 4 } & Frequency (\%) & Graduate & Frequency (\%) \\
\cline { 2 - 4 } & & Frequency (\%) & 1 \\
\hline Poor & 1 & 0 & $(2 \%)$ \\
\hline Good & $(2.70 \%)$ & $11(84.62 \%)$ & 38 \\
& 27 & & $11(22 \%)$ \\
\hline Excellent & $9(2.97 \%)$ & $2(15.38 \%)$ & $50(100 \%)$ \\
\hline Total & $37(100 \%)$ & $13(100 \%)$ & \\
\hline
\end{tabular}

Table 12 shows that $22 \%$ were rated excellent. $76 \%$ rated good and $2 \%$ rated poor. Among school \& plus $24.32 \%$ rated excellent, $72.97 \%$ rated good and $2.70 \%$ were rated poor. Among graduate \&post graduate $22 \%$ excellent, $76 \%$ rated good and $2 \%$ poor. It means there is only a slight variation between educational status and information given by nurses.

Table 13:- Distribution of sample based on patients' satisfaction about information given by nurses and Income category. $\mathrm{N}=50$

\begin{tabular}{|c|c|c|c|c|}
\hline \multirow{2}{*}{$\begin{array}{c}\text { Satisfaction } \\
\text { of patient }\end{array}$} & A & B1,B \& C & D & Total \\
\cline { 2 - 5 } & Frequency & Frequency (\%) & Frequency & Frequency \\
\hline Poor & $(\%)$ & & $(\%)$ & $(\%)$ \\
\hline Good & 0 & $1(5 \%)$ & 0 & 1 \\
\hline Excellent & $1(66.67 \%)$ & $17(85 \%)$ & $19(70.37 \%)$ & $38(76 \%)$ \\
\hline Total & $3(100 \%)$ & $2(10 \%)$ & $8(29.63 \%)$ & $11(22 \%)$ \\
\hline
\end{tabular}

Table 13 shows that among A category 33.33\% rated excellent, among B1,B \&C category 10 rated excellent and among D category $29.63 \%$ rated excellent. Among income category only $1 \%$ rated poor. There is no marked variation between income category and information given by nurses. 
Table 14:- Distribution of sample based on patients' satisfaction about information given by nurses and to length of stay. $\mathrm{N}=50$

\begin{tabular}{|c|c|c|c|}
\hline \multirow{2}{*}{$\begin{array}{c}\text { Satisfaction } \\
\text { Of } \\
\text { Patient }\end{array}$} & $\leq 10$ days & $>10$ days & Total \\
\cline { 2 - 4 } & Frequency(\%) & Frequency(\%) & $1(2 \%)$ \\
\hline Poor & $1(2.64 \%)$ & 0 & $38(76 \%)$ \\
\hline Good & $31(73.68 \%)$ & $7(83.33 \%)$ & $11(22 \%)$ \\
\hline Excellent & $9(23.68 \%)$ & $2(16.67 \%)$ & $50(100 \%)$ \\
\hline Total & $41(100 \%)$ & $9(100 \%)$ & $(\%)$ \\
\hline
\end{tabular}

Table 14 shows that majority of sample $\leq 10$ days $(73.68 \%) \&$ among $>10$ days $(83.33 \%)$ were rated good. Among $\leq$ days $32.68 \%$ rated good and $2.64 \%$ rated poor. Among 10 days $16.67 \%$ rated excellent and no one rated poor.

Table 15:- Distribution of sample based on patients' satisfaction about information given by nurses and previous admission. $\mathrm{N}=50$

\begin{tabular}{|c|c|c|c|}
\hline \multirow{2}{*}{$\begin{array}{c}\text { Satisfaction of } \\
\text { Patient }\end{array}$} & Yes & No & Total \\
\cline { 2 - 4 } & Frequency $(\%)$ & Frequency( \%) & Frequencyv(\%) \\
\hline Poor & $1(2.78 \%)$ & 0 & $38(2 \%)$ \\
\hline Good & $26(72.22 \%)$ & $12(85.71 \%)$ & $11(22 \%)$ \\
\hline Excellent & $9(14.29 \%)$ & $2(14.29 \%)$ & $50(100 \%)$ \\
\hline Total & $36(100 \%)$ & $14(100 \%)$ & \\
\hline
\end{tabular}

Table 15 shows that majority of samples $76 \%$ were rated good. Among previously admitted $14.29 \%$ \& among previously not admitted $14.29 \%$ were rated excellent. It may be noted that there is no difference between information given by nurses and previous admission.

Table 16:- Distribution of sample based on criteria quality of nursing care $\mathrm{N}=50$

\begin{tabular}{|c|c|c|}
\hline Quality of nursing care & Frequency & Percentage \\
\hline Good & 34 & 68 \\
\hline Excellent & 16 & 32 \\
\hline Total & 50 & 100 \\
\hline
\end{tabular}

Table 16 shows that 34(68\%) samples were rated good.16 (32\%) were reported excellent and no one rated poor.

Table 17:- Distribution of sample based on quality of nursing care and age. $\mathrm{N}=50$

\begin{tabular}{|c|c|c|c|}
\hline Quality & $<45$ & $\geq 45$ & Total \\
\hline $\begin{array}{l}\text { Of } \\
\text { nursing care }\end{array}$ & Frequency (\%) & Frequency $(\%)$ & Frequency $(\%)$ \\
\hline Good & $17(68 \%)$ & $17(68 \%)$ & $34(68 \%)$ \\
\hline Excellent & $\begin{array}{l}8 \\
(32 \%)\end{array}$ & $8(32 \%)$ & $16(32 \%)$ \\
\hline Total & $\begin{array}{l}25 \\
(100 \%)\end{array}$ & $25(100 \%)$ & $50(100 \%)$ \\
\hline
\end{tabular}

Table 18:- Distribution of sample based on quality of nursing care and sex. N=50

\begin{tabular}{|c|c|c|c|}
\hline Quality of nursing & Female & Male & Total \\
\hline Care & Frequency (\%) & Frequency (\%) & \\
\hline Good & $11(64.71 \%)$ & $23(69.70 \%)$ & $34(68 \%)$ \\
\hline Excellent & $6(35.29 \%)$ & $10(30.30 \%)$ & $16(32 \%)$ \\
\hline Total & $17(100 \%)$ & $33(100 \%)$ & $50(100 \%)$ \\
\hline
\end{tabular}

Table 18 shows that among females and males majority rated good. $35.29 \%$ females and $30.30 \%$ males rated excellent. There is no marked relation between quality of nursing care and sex. 
Table 19:- Distribution of sample based on quality of nursing care and marital status. $\mathrm{N}=50$

\begin{tabular}{|c|c|c|c|}
\hline \multirow{2}{*}{$\begin{array}{c}\text { Quality } \\
\text { of } \\
\text { nursing care }\end{array}$} & Single & Married & Total \\
\cline { 2 - 4 } & Frequency $(\%)$ & $28(68.29 \%)$ & $34(68 \%)$ \\
\hline Good & $6(66.67 \%)$ & $13(31.71 \%)$ & $16(32 \%)$ \\
\hline Excellent & $3(33.33 \%)$ & $41(100 \%)$ & $50(100 \%)$ \\
\hline Total & $9(100 \%)$ & Frequency $(\%)$ & \\
\hline
\end{tabular}

Table 19 shows that there is no marked variation between marital status and quality of nursing care. Among that $34(68 \%)$ were rated good and 16(32\%) were excellent.

Table 20:- Distribution of sample based on quality of nursing care and education. $\mathrm{N}=50$.

\begin{tabular}{|l|l|l|l|}
\hline $\begin{array}{l}\text { Quality } \\
\text { of } \\
\text { nursing care }\end{array}$ & $\begin{array}{l}\text { School\& plus 2 } \\
\text { Frequency }(\%)\end{array}$ & $\begin{array}{l}\text { Graduate \&post } \\
\text { graduate }\end{array}$ & Total \\
\hline Good & $28(75.68 \%)$ & $6(46.15 \%)$ & $34(68 \%)$ \\
\hline Excellent & $9(24.32 \%)$ & $7(53.85 \%)$ & $16(32 \%)$ \\
\hline Total & $37(100 \%)$ & $13(100 \%)$ & $50(100 \%)$ \\
\hline
\end{tabular}

Table 20 shows that majority of the sample from school and plus2 were rated good 28(75.68\%) and majority of the sample from graduate and post graduate rated excellent $7(53.85 \%)$.

Table 21:- Distribution of sample based on quality of nursing care and income category $\mathrm{N}=50$

\begin{tabular}{|l|l|l|l|l|}
\hline \multirow{2}{*}{$\begin{array}{l}\text { Quality } \\
\text { of } \\
\text { nursing care }\end{array}$} & A & B1, B \& C & D & Total \\
\cline { 2 - 5 } & Frequency & Frequency & Frequency & Frequency \\
\hline Good & $(\%)$ & $(\%)$ & $(\%)$ & $(\%)$ \\
\hline Excellent & $1(33.33 \%)$ & $14(70 \%)$ & $19(70.37 \%)$ & $34(68 \%)$ \\
\hline Total & $2(66.67 \%)$ & $6(30 \%)$ & $8(29.63 \%)$ & $16(32 \%)$ \\
\hline
\end{tabular}

Table 21 shows that majority of sample from B1,B\& C 70\%, from D category 19(70.37\%) rated good and majority of sample from A category 2(66.67\%) were rated excellent.

Table 22:- Distribution of sample based on quality of nursing care and length of stay $\mathrm{N}=50$

\begin{tabular}{|c|c|c|c|}
\hline \multirow{2}{*}{$\begin{array}{c}\text { Quality } \\
\text { of } \\
\text { nursing care }\end{array}$} & $\leq 10$ days & $>10$ & days \\
\cline { 2 - 4 } & Frequency $(\%)$ & Frequency $(\%)$ & Frequency $(\%)$ \\
\hline Good & $29(76.39 \%)$ & $5(41.67 \%)$ & $34(68 \%)$ \\
\hline Excellent & $9(23.68 \%)$ & $7(58.33 \%)$ & $16(32 \%)$ \\
\hline Total & $38(100 \%)$ & $12(100 \%)$ & $50(100 \%)$ \\
\hline
\end{tabular}

Table 22 shows that among $\leq 10$ days 29(76.39\%) were rated good, $23.68 \%$ rated excellent and among $>10$ days $58.33 \%$ rated excellent $7(58.33 \%), 41.67 \%$ rated good.

Table 23:- Distribution of sample based on quality of nursing care and previous admission $\mathrm{N}=50$

\begin{tabular}{|c|c|c|c|}
\hline $\begin{array}{c}\text { Quality } \\
\text { of } \\
\text { nursing care }\end{array}$ & $\begin{array}{c}\text { Yes } \\
\text { Frequency }(\%)\end{array}$ & $\begin{array}{c}\text { No } \\
\text { Frequency }(\%)\end{array}$ & $\begin{array}{c}\text { Total } \\
\text { Frequency }(\%)\end{array}$ \\
\hline Good & $10(71.43 \%)$ & $24(66.67 \%)$ & $34(68 \%)$ \\
\hline Excellent & $4(28.57 \%)$ & $12(33.33 \%)$ & $16(32 \%)$ \\
\hline Total & $14(100 \%)$ & $36(100 \%)$ & $50(100 \%)$ \\
\hline
\end{tabular}

Table 23 shows that $10(71.43 \%)$ previously admitted samples and 24(66.67\%) previously not admitted samples were rated good. $4(28.57 \%)$ previously admitted and $12(33.33 \%)$ previously not admitted were rated excellent. There is only a slight variation between quality of nursing care and previous admission. 
Table 24;- Distribution of sample according to overall patient satisfaction with quality of nursing care. $\mathrm{N}=50$

\begin{tabular}{|c|c|c|}
\hline $\begin{array}{c}\text { Overall patient } \\
\text { satisfaction with quality } \\
\text { of nursing care }\end{array}$ & Frequency & Percentage (\%) \\
\hline Excellent & 15 & 30 \\
\hline Good & 35 & 70 \\
\hline Total & 50 & 100 \\
\hline
\end{tabular}

Table 24 shows that distribution of sample according to overall patient satisfaction with nursing quality of care. 15 (30\% were rated excellent, $35(70 \%)$ were rated good and no one rated poor.

Table 25:- Association of overall patient satisfaction with quality of nursing care and selected variables. N=50

\begin{tabular}{|c|c|c|c|c|}
\hline \multirow{2}{*}{$\begin{array}{l}\text { Different } \\
\text { Variables }\end{array}$} & \multicolumn{2}{|c|}{ Patient Satisfaction } & \multirow[t]{3}{*}{ Total } & \multirow[t]{3}{*}{ P-value } \\
\hline & \multirow{2}{*}{$\begin{array}{l}\text { Excellent } \\
(\%)\end{array}$} & \multirow{2}{*}{$\begin{array}{l}\text { Good } \\
(\%)\end{array}$} & & \\
\hline \multirow[t]{2}{*}{ Age } & & & & \\
\hline & \multirow[t]{2}{*}{$4(16 \%)$} & \multirow[t]{2}{*}{$21(84 \%)$} & \multirow[t]{2}{*}{$25(100 \%)$} & \multirow[t]{3}{*}{0.031} \\
\hline$<45$ & & & & \\
\hline$\geq 45$ & $11(44 \%)$ & $14(56 \%)$ & $25(100 \%)$ & \\
\hline \multirow[t]{2}{*}{ Sex } & & & & \\
\hline & \multirow[t]{2}{*}{$12(36.36 \%)$} & \multirow[t]{2}{*}{$21(63.64 \%)$} & \multirow[t]{2}{*}{$33(100 \%)$} & \multirow[t]{3}{*}{0.148} \\
\hline Male & & & & \\
\hline Female & $3(17.65 \%)$ & $14(82.35 \%)$ & $17(100 \%)$ & \\
\hline \multirow[t]{2}{*}{ Marital status } & & & & \\
\hline & \multirow[t]{2}{*}{$4(44.44 \%)$} & \multirow[t]{2}{*}{$5(55.6 \%)$} & \multirow[t]{2}{*}{$9(100 \%)$} & \multirow[t]{3}{*}{0.25} \\
\hline Single & & & & \\
\hline Married & $11(26.8 \%)$ & $30(73.2 \%)$ & $41(100 \%)$ & \\
\hline \multirow[t]{2}{*}{ Education } & & & & \\
\hline & \multirow[t]{2}{*}{$11(29.7 \%)$} & \multirow[t]{2}{*}{$26(70.3 \%)$} & \multirow[t]{2}{*}{$37(100 \%)$} & \multirow[t]{3}{*}{0.602} \\
\hline \multirow{2}{*}{\multicolumn{4}{|c|}{$\begin{array}{l}\text { School \&plus2 } \\
\text { Graduate\& }\end{array}$}} & \\
\hline & & & & \\
\hline \multicolumn{5}{|l|}{ Postgraduate } \\
\hline \multirow[t]{2}{*}{ Income category } & & & & \\
\hline & \multirow[t]{2}{*}{$1(33.3 \%)$} & $2(66.7 \%)$ & $3(100 \%)$ & 0.88 \\
\hline A & & & & \\
\hline $\mathrm{B} 1, \mathrm{~B} \& \mathrm{C}$ & $5(25 \%)$ & $15(75 \%)$ & $20(100 \%)$ & \\
\hline $\mathrm{D}$ & $9(33.3 \%)$ & $18(66.7 \%)$ & $27(100 \%)$ & \\
\hline$>10$ days & $2(23.2 \%)$ & $7(77.8 \%)$ & $9(100 \%)$ & \\
\hline Previous & & & & 0.40 \\
\hline admission & $10(27.8 \%)$ & $26(72.2 \%)$ & $36(100 \%)$ & \\
\hline Yes & & & & \\
\hline No & $5(35.7 \%)$ & $9(64.3 \%)$ & $14(100 \%)$ & \\
\hline
\end{tabular}

Table 25 shows that age $<45$ excellent (16\%), good (84\%) and age $\geq 45$ excellent (44\%), good (56\%) (P-value 0.031 ) it shows statistically significant relation between age group and patient satisfaction with quality of nursing care. Male $36.6 \%$ were excellent, $63.64 \%$ were good and female $17.65 \%$ were excellent, $82.35 \%$ were good (p-value 0.05 ) shows statistically no significant relation between sex and patient satisfaction. Married 26.8\%were excellent, $73.2 \%$ were good and single $44.4 \%$ were excellent, $55.6 \%$ were good (p-value 0.25 ) shows statistically no significant relation between marital status and patient satisfaction. In School \&plus2 29.7\% were excellent, $70.3 \%$ were good and graduate and post graduate $30.7 \%$ were excellent, $69.35 \%$ were good(p-value 0.602$)$ shows statistically no significant relation between education and patient satisfaction. Income category A category33.3\% were excellent, $66.7 \%$ were good, category B1 B C 25\% were excellent $75 \%$ were good, D $33.3 \%$ were excellent, $66.7 \%$ were good( p-value 0.88 ) there is no significant relation between income category and patient satisfaction. 
Table 4.4:- Distribution of sample based on quality of nursing care and income category

\begin{tabular}{|l|l|l|l|l|}
\hline $\begin{array}{l}\text { Quality } \\
\text { of } \\
\text { nursing care }\end{array}$ & $\begin{array}{l}\text { A } \\
\text { Frequency } \\
(\%)\end{array}$ & $\begin{array}{l}\text { B1, B \& C } \\
\text { Frequency } \\
(\%)\end{array}$ & $\begin{array}{l}\text { D } \\
\text { Frequency } \\
(\%)\end{array}$ & $\begin{array}{l}\text { Total } \\
\text { Frequency } \\
(\%)\end{array}$ \\
\hline Good & $1(33.33 \%)$ & $14(70 \%)$ & $19(70.37 \%)$ & $34(68 \%)$ \\
\hline Excellent & $2(66.67 \%)$ & $6(30 \%)$ & $8(29.63 \%)$ & $16(32 \%)$ \\
\hline Total & $3(100 \%)$ & $20(100 \%)$ & $27(100 \%)$ & $50(100 \%)$ \\
\hline
\end{tabular}

Table4.4 shows that majority of sample from B1,B\& C 70\%, from D category $19(70.37 \%)$ rated good and majority of sample from A category 2(66.67\%) were rated excellent.

According to length of hospital stay $\leq 10$ days $30 \%$ were excellent, $70 \%$ were good and $>10$ days $23.2 \%$ were excellent, $77.8 \%$ were good ( $\mathrm{p}$-value0.493) there is no significant relation with length of stay and patient satisfaction. According to previous admission $27.8 \%$ were excellent, $72.22 \%$ were good and previously not admitted $35.7 \%$ were reported excellent, $64.3 \%$ were good (p- value 0.4 ) there is no significant relation between patient satisfaction and previous admission.

\section{Limitation:-}

Patients who can read and understand Hindi. The Sample size limited to 50 Patients who have age above 18 years. The study was limited to neuromedical unit.

\section{Major findings of the study:-}

Total number of sample was 50. The mean age of patients was $44.7 \mathrm{yrs,}$, standard deviation 16.88. Patient satisfaction with quality nursing care $<45$ ranges from excellent $4(16 \%)$ and good $21(84 \%), \geq 45$ ranges from excellent $11(44 \%)$ and $14(56 \%)$.By doing unpaired t- test (p-value 0.031 ) there is statistical difference in patient satisfaction with nursing care with regard to age and no statistical difference in patient satisfaction with sex, marital status, education, income category, length of stay and previous admission.

\section{Recommendations:-}

On the basis of findings following recommendations were made for future research. Similar study would be repeated in other intensive care units and wards of this institute. Similar study can be repeated by increasing the size of the sample.

\section{Conclusion:-}

A descriptive study was undertaken to assess the Patient Satisfaction with Quality of Nursing care in neuromedical department in SGT, Hospital, Haryana. The study was conducted in sample of 50 patients. Based on the finding of the study the following conclusion was drawn. Study shows that $70 \%$ patients" rated overall patient satisfaction with quality nursing care was good and $30 \%$ were rated excellent and no one rated poor. There was statistically significant relation between age and satisfaction of patient ( $\mathrm{p}-0.031)$ and no relation between other variables.

\section{Reference:-}

1. Abramowitz S, Berry E, Cott A A. „Analyzing patient satisfaction; A multi analytic approach. Q Quality review bulletin 1987; 13: 122-130.

2. Andaleeb $\mathrm{S}$,Service quality and patient satisfaction, A study of Hospitals in a developing country. ${ }^{\text {.e SocSci }}$ Med 2011; 52:1359-70.

3. Chang et al. „Evaluating quality of nursing care: The gap between Theory and Practice. “ The Journal of nursing administration 2002; 32 (7/8):405-18.

4. Chang E, Hancock K, Chenoweth L, Jean C. "The Influence of demographic variables and type on elderly patient ${ }^{\text {ee }}$ perception of need and satisfaction

5. during hospitalization”. International Journal of nursing practice 2003; 9 [3]: 191-201.

6. Erickson L R. ,Patient satisfaction: -an indicator of nursing care quality. " J nurse management 1987; 18: 31-35.

7. Fahad A F. ,The effect of nursing care on overall patient satisfaction and its predictive value on return-toprovider behavior. A survey study." Quality

8. management in health care 2005; 14 [2]: 337-44.

9. Findik U Y and Unsar S „Patient satisfaction with nursing care and its relationship with patient characteristics. Nursing and Health Sciences 2010; 
10. $12[2]: 162-69$.

11. Foss C. „Gender bias in nursing care? Gender - related in patient satisfaction with quality of nursing care ${ }^{e e}$ Scandinavian journal of caring nurses 2002; 16 [1]: 19-26.

12. Harkreader H \& Hogan M A. „Fundamentals of nursing caring \& clinical judgement ${ }^{\text {ee }}$.Elsiver science 2004;2: 45-51. 